\title{
Immunolocalization of androgen receptors in the canine ovary and their relation to sex steroid hormone concentrations
}

\author{
H. Vermeirsch ${ }^{1}$, P. Simoens ${ }^{1}$, M. Coryn ${ }^{2}$ and W. Van den Broeck ${ }^{1}$ \\ Departments of ${ }^{1}$ Morphology and ${ }^{2}$ Reproduction, Obstetrics and Herd Health, Faculty of \\ Veterinary Medicine, Ghent University, Salisburylaan 133, B-9820 Merelbeke, Belgium
}

\begin{abstract}
Androgens play an essential role as autocrine or paracrine agents in ovarian follicular growth, maturation and luteinization. The aim of this study was to describe the normal cellular distribution of androgen receptors in the canine ovary at different stages of the oestrous cycle. Samples of both ovaries were obtained from 34 dogs, including six pregnant animals and three that had just produced litters. Presence of androgen receptors was visualized by immunohistochemistry on paraffin wax sections using a polyclonal antibody. Nuclear staining for androgen receptors was observed in the surface epithelium, cortical tubules, rete ovarii, follicle cells, thecal cells, luteal cells, granulosa cell cords and ovarian stroma, indicating that androgens have important roles in ovarian function in bitches. In theca interna cells of tertiary follicles, androgen production seems to be more
\end{abstract}

important than androgen receptivity, as immunostaining for androgen receptors in these cells was weak compared with that in other ovarian stromal cells. In primordial and primary follicles, the immunostaining for androgen receptors was rather weak, indicating that androgens are of minor importance in early preantral follicles. In follicle cells of larger preantral and antral follicles, the immunostaining for androgen receptors increased with the stage of the follicle. Corpora lutea expressed less immunostaining, which was not correlated with serum progesterone concentrations, although local actions of progesterone on androgen receptors in corpora lutea cannot be excluded. In general, few correlations were found between immunostaining for androgen receptors and serum sex steroid concentrations, indicating that other factors regulate androgen receptors in the canine ovary.

\section{Introduction}

Androgens play an essential role as autocrine or paracrine agents in follicular growth, maturation and luteinization (Harlow et al., 1986,1988; Hild-Petito et al., 1991; Horie et al., 1992; Chadha et al., 1994; Suzuki et al., 1994; Hillier and Tetsuka, 1997). This role is illustrated by the fact that hyperandrogenic women have more developing follicles than do normal cyclic women (Vendola et al., 1998) owing to the trophic effects of androgens (Weil et al., 1998). Androgen activity is the sum of a direct effect mediated by androgen receptors and an indirect effect of oestrogens produced by aromatization of androgens (Horie et al., 1992). Both hormones are essential for the maturation of ovarian follicles and normal fertility (Saunders et al., 2000). Steroidal and non-steroidal factors, including androgens, produced locally are thought to modulate FSH responsiveness at intermediate stages of development of ovarian follicles (Weil et al., 1999). Furthermore, in primates, the expression of androgen receptor mRNA is positively correlated with granulosa cell proliferation and follicular growth, and negatively correlated with granulosa cell apoptosis and follicular atresia (Weil et al., 1998).

Email: Hilde.Vermeirsch@rug.ac.be
Therefore, androgen receptor gene expression may be a marker for normal follicle growth that may depend upon thecal androgens stimulating proliferation and survival of granulosa cells in a paracrine fashion.

In this study, an immunohistochemical technique was used to demonstrate the normal distribution of androgen receptors in the various ovarian cell types in 34 dogs. To the authors' knowledge, the precise localization of androgen receptors in the canine ovary has not yet been described. The study also investigated whether changes in the distribution of androgen receptors occurred throughout the different stages of the oestrous cycle and whether the presence of androgen receptors in different groups of ovarian cell was correlated with the serum concentrations of oestradiol, progesterone and testosterone. The knowledge of the localization and expression of the androgen receptors during the oestrous cycle may lead to a better understanding of hormonal regulation of the ovarian cycle and endocrinological ovarian pathology, such as the development of cystic ovaries.

This study is part of a global investigation on sex steroid receptors in the different tissues of the canine female genital tract. Earlier studies determined the localization of oestrogen receptors $\alpha$ in uterine tissue (Vermeirsch et al., 1999) and progesterone receptors in uterine and ovarian tissue (Vermeirsch et al., 2000a, 2001). 
Table 1. Number of dogs at each stage of the oestrous cycle $(n)$ and corresponding mean $( \pm \mathrm{SD})$ serum concentrations of sex steroids

\begin{tabular}{lcccc}
\hline Stage of cycle & $n$ & Mean serum progesterone $\left(\mathrm{ng} \mathrm{ml}^{-1}\right)$ & Mean serum oestradiol $\left.(\mathrm{pg} \mathrm{ml})^{-1}\right)$ & Mean serum testosterone $\left(\mathrm{ng} \mathrm{ml}^{-1}\right)$ \\
\hline Pro-oestrus & 5 & $0.47 \pm 0.06$ & $22.40 \pm 6.11$ & $0.16 \pm 0.03$ \\
Oestrus & 5 & $4.51 \pm 3.76$ & $16.40 \pm 9.74$ & $0.12 \pm 0.06$ \\
Early metoestrus & 5 & $14.79 \pm 4.14$ & $9.50 \pm 2.38$ & $0.09 \pm 0.06$ \\
Late metoestrus & 5 & $1.31 \pm 1.02$ & $5.67 \pm 5.51$ & $0.08 \pm 0.03$ \\
Anoestrus & 5 & $0.83 \pm 0.69$ & $1.60 \pm 0.89$ & $0.05 \pm 0.03$ \\
\hline
\end{tabular}

\section{Materials and Methods}

\section{Tissue sampling}

Samples of both ovaries and uterine horns were obtained from 34 healthy adult bitches presented for ovariohysterectomy at the Faculty of Veterinary Medicine in Ghent, Belgium, and at two veterinary clinics. For each bitch, data concerning anamnesis, weight, litters and last pro-oestrus bleeding were recorded. The bitches varied in age from 1 to 12 years, were from various breeds and were different from those used in our previous study on progesterone receptor expression (Vermeirsch et al., 2001). Animals were sedated using medetomedine $\left(40-50 \mu \mathrm{g} \mathrm{kg}^{-1}\right.$ i.m.) (Domitor; Orion Corporation, Espoo) and subsequently anaesthetized with thiopental (8 $\mathrm{mg} \mathrm{kg}^{-1}$ i.v.) (Pentothal; Abbot Laboratories, North Chicago, IL). After intubation, anaesthesia was maintained by halothane. Directly after excision, the tissue samples were fixed for $48 \mathrm{~h}$ in $3.5 \%$ ( $\mathrm{v} / \mathrm{v})$ phosphate-buffered formaldehyde $(\mathrm{pH}$ 6.7).

Serum samples were taken immediately before surgery and stored at $-20^{\circ} \mathrm{C}$ until assayed for serum concentrations of progesterone, oestradiol and testosterone using the radioimmunoassay technique described by Coryn et al. (1981) and Henry et al. (1987).

\section{Staging of the oestrous cycle}

The stage of the oestrous cycle of each bitch was determined in the same way as for the bitches used in previous receptor studies (Vermeirsch et al., 1999, 2000a). Animals were first sorted by histological examination of the ovaries and uterus, using the classification of Andersen and Simpson (1973), combined with the macroscopic evaluation of the female genital tract including both ovaries. After this preliminary classification, the animals were sorted further according to serum progesterone concentrations (Concannon, 1986a; Concannon et al., 1989). Animals with uterine tissue at a proliferative stage and a progesterone concentration $<1 \mathrm{ng} \mathrm{ml}^{-1}$ were classified as being in prooestrus. Animals with uterine tissue at a late proliferative to early secretory stage and a progesterone concentration between 1 and $10 \mathrm{ng} \mathrm{ml}^{-1}$ were classified as being in oestrus. Animals with uterine tissue at a secretory stage were classified as being in early metoestrus when progesterone concentrations were $>10 \mathrm{ng} \mathrm{ml}^{-1}$, and in late metoestrus when progesterone concentrations were $<10 \mathrm{ng} \mathrm{ml}^{-1}$. Animals with uterine tissue at an inactive stage were classified in the anoestrous group. The number of animals and mean serum hormone concentrations in each stage are listed (Table 1). Samples from five bitches were obtained per cycle stage. Samples of six pregnant bitches (at days 23, $26,34,37,38$ and 42 of gestation) were also obtained. The day of gestation was estimated using the crown-rump length of the fetuses (Evans, 1993; Vermeirsch et al., $2000 b)$. Ovaries were also obtained at $1-3$ days post partum from three bitches that had just delivered.

\section{Immunohistochemistry}

All tissue samples were embedded in paraffin wax, and $5 \mu \mathrm{m}$ sections were cut, mounted on 3-aminopropyltriethoxysilane-coated (APES; Sigma, St Louis, MO) slides and dried overnight at $37^{\circ} \mathrm{C}$. After deparaffinizing in xylene and rehydratation, the sections were pretreated in an antigen retrieval citra solution (BioGenex, San Ramon, CA). This pretreatment consisted of microwaving the slides for $2 \mathrm{~min}$ at $700 \mathrm{~W}$, and then for 3,5 and $5 \mathrm{~min}$ at $200 \mathrm{~W}$ with intervals of $5 \mathrm{~min}$. After cooling for $30 \mathrm{~min}$ at $4^{\circ} \mathrm{C}$ and rinsing in distilled water, the slides were incubated for 5 min with a $3 \%(\mathrm{v} / \mathrm{v}) \quad \mathrm{H}_{2} \mathrm{O}_{2}$ to block endogenous peroxidase. The slides were rinsed in Tris-buffered saline (TBS) and incubated with a $30 \%(\mathrm{v} / \mathrm{v})$ TBS solution of normal goat serum for $30 \mathrm{~min}$ at $25^{\circ} \mathrm{C}$, to prevent nonspecific reactions. All incubations were carried out in a humidified environment. The actual immunohistochemical detection of androgen receptors was performed using a polyclonal rabbit-anti-human androgen receptor antibody (NCL-ARp; Novocastra Laboratories, Ltd, Newcastle upon Tyne). Each tissue section was incubated overnight at $4^{\circ} \mathrm{C}$ with a 1:20 dilution of the concentrated primary antibody. After rinsing in TBS, the sections were incubated for $30 \mathrm{~min}$ at $25^{\circ} \mathrm{C}$ with a $1: 500$ dilution of the secondary goat-antirabbit antibody bound to biotin (E0432; DAKO, Glostrup), and a 1:1000 dilution of peroxidase-conjugated streptavidin (P0397; DAKO), respectively. Finally, after rinsing all sections in TBS, diaminobenzidine (DAB) chromogen substrate (Liquid DAB+; DAKO) was administered for 12.5 min. Reaction of $D A B$ with peroxidase produces a brown staining. Mayer's haematoxylin was applied as a nuclear counterstain. In every staining procedure, positive 
and negative controls were included. The positive controls were human and canine prostate tissue. Negative controls included incubations of canine uterine tissue and prostate tissue with omission of primary antibody, secondary antibody, streptavidin or DAB chromogen substrate.

\section{Evaluation of immunohistochemical staining and statistical methods}

One tissue section of each ovary from each animal was stained. The receptor expression in each tissue section was examined three times using a light microscope at $\times 400$ magnification. The microscopist was unaware of which animal or stage the tissue was from. In each section, the immunostaining was evaluated in terms of the following groups of cells when present: surface epithelium, cortical tubules, rete ovarii, follicle cells, thecal cells, luteal cells, granulosa cell cords and ovarian stroma. Each positively staining group of cells was given an immunohistochemical total score, consisting of the addition of an intensity score and a proportional score. The intensity score reflected the intensity of the brown-positive staining in the cell nuclei or cytoplasm, whereas the proportional score reflected the percentage of cell nuclei that stained positive in the different groups of cells (Table 2). This proportional score was based on all cells of the surface epithelium, rete ovarii and cortical tubules and on representative areas of the other groups of cells. In these representative areas, up to 100 cells were evaluated. For the stroma, the stroma cells lying between follicles were evaluated. Scores were determined in morphologically normal follicles, that is, follicles not displaying signs of atresia. These follicles were classified into primordial, primary, secondary and tertiary follicles according to the criteria listed by the Nomina Histologica (International Committee on Veterinary Histological Nomenclature, 1994). Note that the term 'follicle cells' includes all cells of a given follicle not including the cells of the theca interna and externa or the oocyte.

A statistical computer program (Statistix for Windows, Analytical Software, Tallahassee) was used to perform the statistical tests. The non-parametric Kruskall-Wallis test was applied to determine whether there was any significant difference in staining throughout the oestrous cycle or among the different groups of cells. The Bonferroni test was used to determine in which particular stages or groups of cells the staining scores were significantly different from one another. The Spearman rank correlation test was used for determination of correlations between the immunohistochemical scores and the serum hormone concentrations. The Spearman rank correlation coefficients $\left(r_{s}\right)$ are given in the results when correlations were significant $(P<0.05)$.

\section{Results}

\section{Localization of androgen receptors}

Immunohistochemically brown staining demonstrating
Table 2. Immunohistochemical grading scores

\begin{tabular}{ll}
\hline Intensity score & Proportional score \\
\hline Score 0 : absent staining & Score $0:$ no positive nuclei \\
Score 1: weak staining & Score $1:<1 \%$ positive nuclei \\
Score 2: moderate staining & Score $2: 1-9 \%$ positive nuclei \\
Score 3: strong staining & Score $3: 10-32 \%$ positive nuclei \\
Score 4: very strong staining & Score $4: 33-65 \%$ positive nuclei \\
& Score $5:>65 \%$ positive nuclei \\
\hline
\end{tabular}

the presence of androgen receptors was observed in the nuclei of different ovarian groups of cells (Figs 1 and 2): the surface epithelium, cortical tubules, rete ovarii, follicle cells, thecal cells, luteal cells, granulosa cell cords and the ovarian stroma. Cytoplasmic staining was observed in lutein cells of the corpus luteum. No staining for androgen receptors was seen in oocytes or blood vessels. Positive staining was absent in all negative controls (Fig. 3).

\section{Variation of androgen receptor expression in different ovarian groups of cells}

Significant differences were found in staining scores among different groups of cells irrespective of the stage of the oestrous cycle (Fig. 4). In ovarian follicles, the staining intensity for androgen receptors in the follicle cells increased with the stage of the follicle. Only a minority of the primordial follicles expressed very weak staining for androgen receptors. Compared with those of the secondary and tertiary follicles, the staining scores of the primordial follicles were significantly lower $(P<0.01)$. Primary follicles had a significantly lower total score than did tertiary follicles $(P<0.05)$. A luteinizing tertiary follicle observed during oestrus had fewer positive follicle cells that stained with a weaker intensity compared with a large antral follicle in the same ovary. In another oestrous ovary, a luteinizing tertiary follicle that had just ovulated, as evidenced by the presence of the stigma, showed no immunostaining for androgen receptors.

The granulosa cell cords, which are thought to originate from atretic secondary follicles, did not stain significantly differently from the follicle cells from secondary follicles and, compared with the ovarian stroma, had a significantly lower intensity score $(P<0.01)$.

The other epithelial cells in the ovary, namely the surface epithelium, cortical tubules and rete ovarii, had different intensity scores. The surface epithelium stained with an intensity that was significantly lower than that of the rete ovarii $(P<0.01)$. In the cortical tubules and rete ovarii, nearly all cells stained positive, whereas the surface epithelium frequently contained negative cells $(P<0.01)$. Consequently, the total score of the surface epithelium was also lower than that of the cortical tubules and the rete ovarii $(P<0.01)$. 

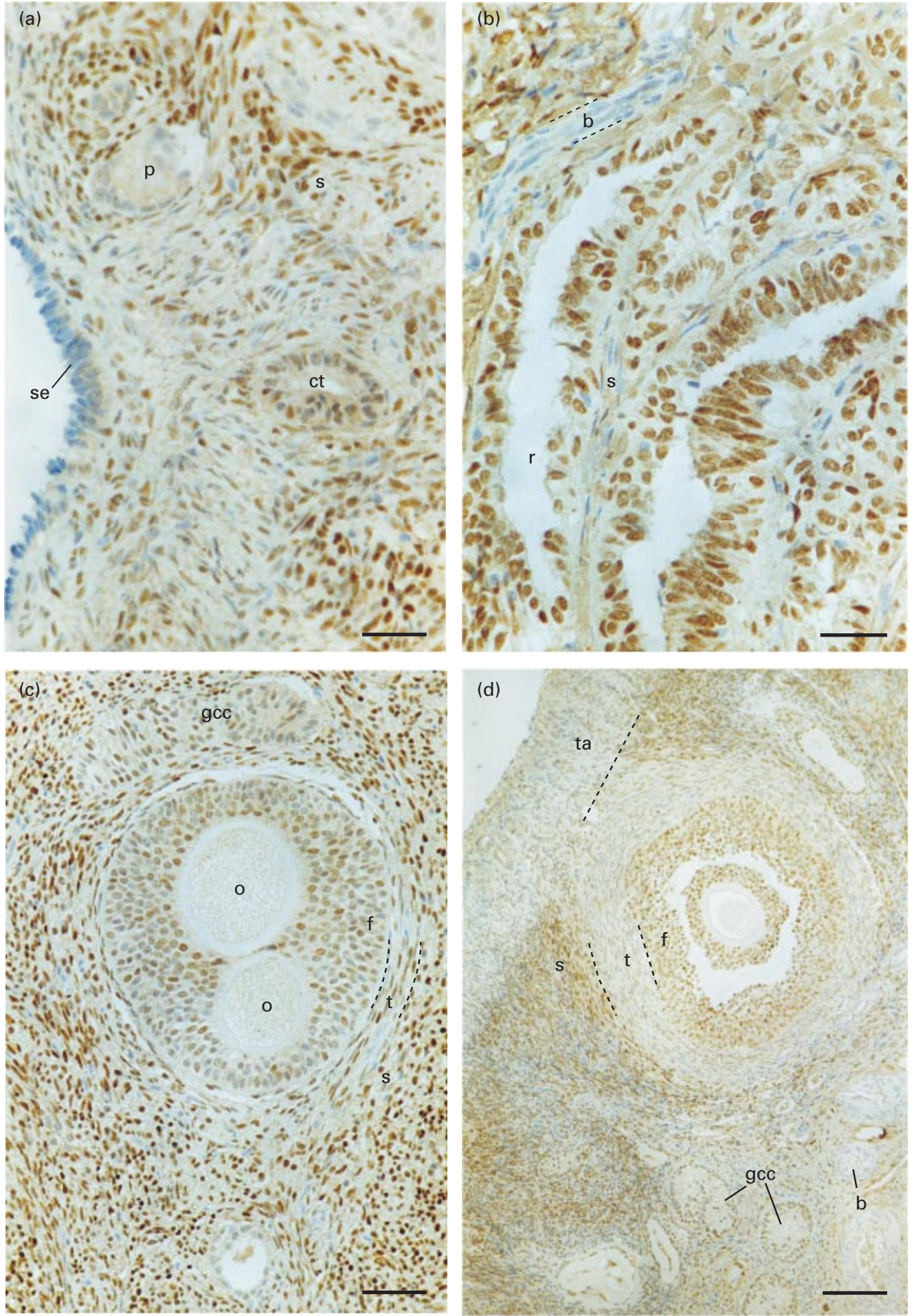

Fig. 1. Immunohistochemical staining for androgen receptors in different groups of canine ovarian cells. (a) Staining for androgen receptors is negative or very weak in the surface epithelium (se) and in follicle cells of primordial follicles (p), weak in the cortical tubules (ct), and moderate in stromal cells (s). (b) The rete ovarii (r) and surrounding stroma (s) also express androgen receptors. Blood vessels (b) are negative. (c) Secondary follicle with two oocytes (o). Moderate staining for androgen receptors is present in the follicle cells ( $f$ ), thecal cells (t) and surrounding stromal cells (s). Some cells of granulosa cell cords (gcc) are weakly positive. (d) The tunica albuginea (ta) and theca layers (t) of a small antral follicle ( $\mathrm{f}$ ) stain positive but with a weaker intensity than the stroma (s). Granulosa cell cords (gcc) stain weakly positive and blood vessels (b) are negative for androgen receptors. Scale bars represent 25 (a,b), 40 (c) and $95 \mu \mathrm{m}$ (d). 

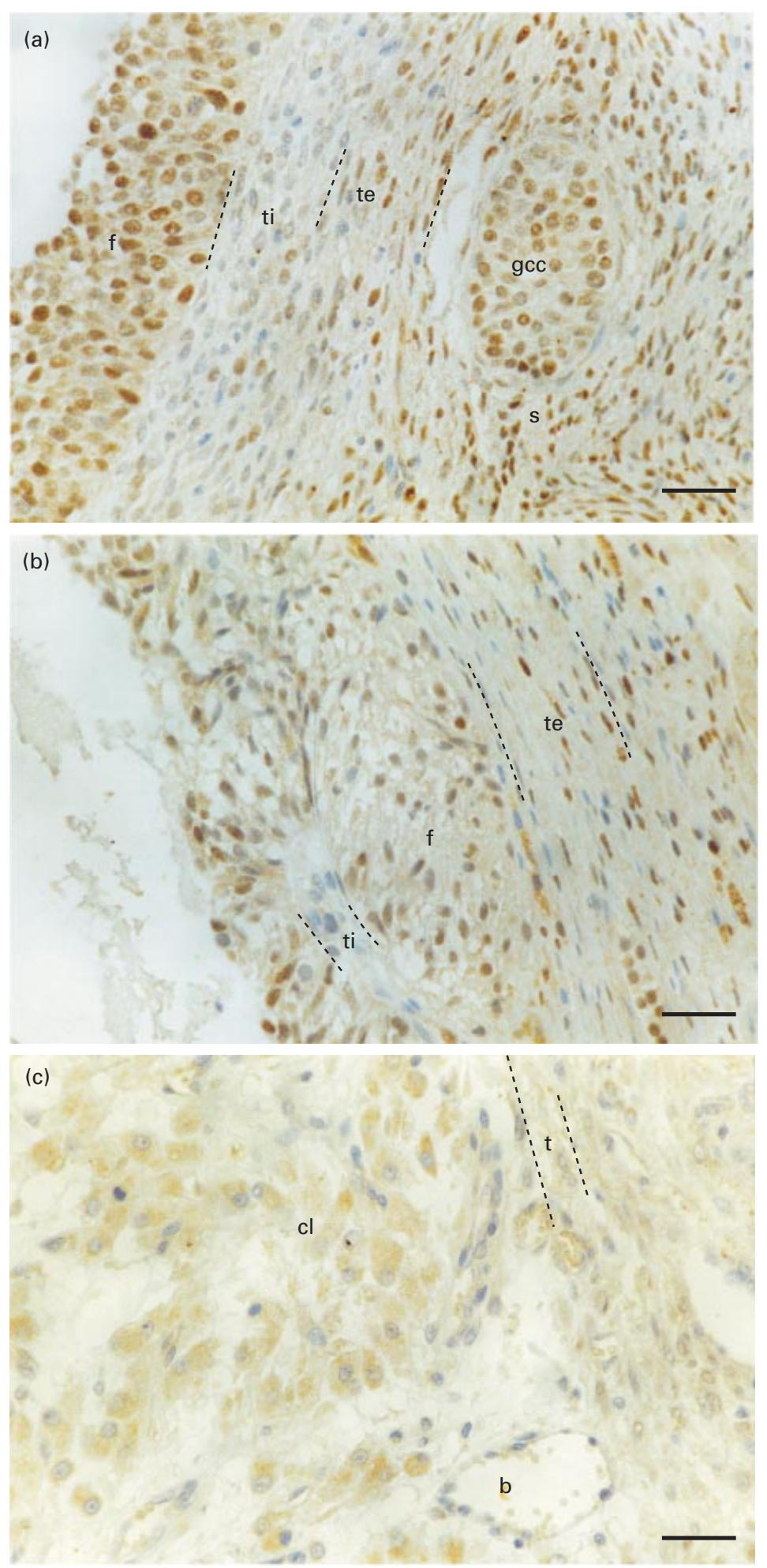

Fig. 2. Immunohistochemical staining for androgen receptors in the tertiary follicles and corpora lutea of the canine ovary. (a) In the follicular wall of large antral follicles, moderately positive staining was observed in the follicle cells (f) and in cells of the theca externa (te), and weak staining in the theca interna cells (ti). The stroma (s) and granulosa cell cords (gcc) also stain moderately positive. (b) In the follicular wall of luteinizing antral follicles, weak-to-moderately positive staining was observed in the follicle cells ( $f$ ) and in the cells of the theca externa (te), whereas most cells of the infolding theca interna (ti) stained negative. (c) In the corpus luteum (cl) during early metoestrus, weak cytoplasmic staining was observed. Surrounding thecal cells (t) and small blood vessels (b) stained negative for androgen receptors. Scale bars represent $25 \mu \mathrm{m}$. 

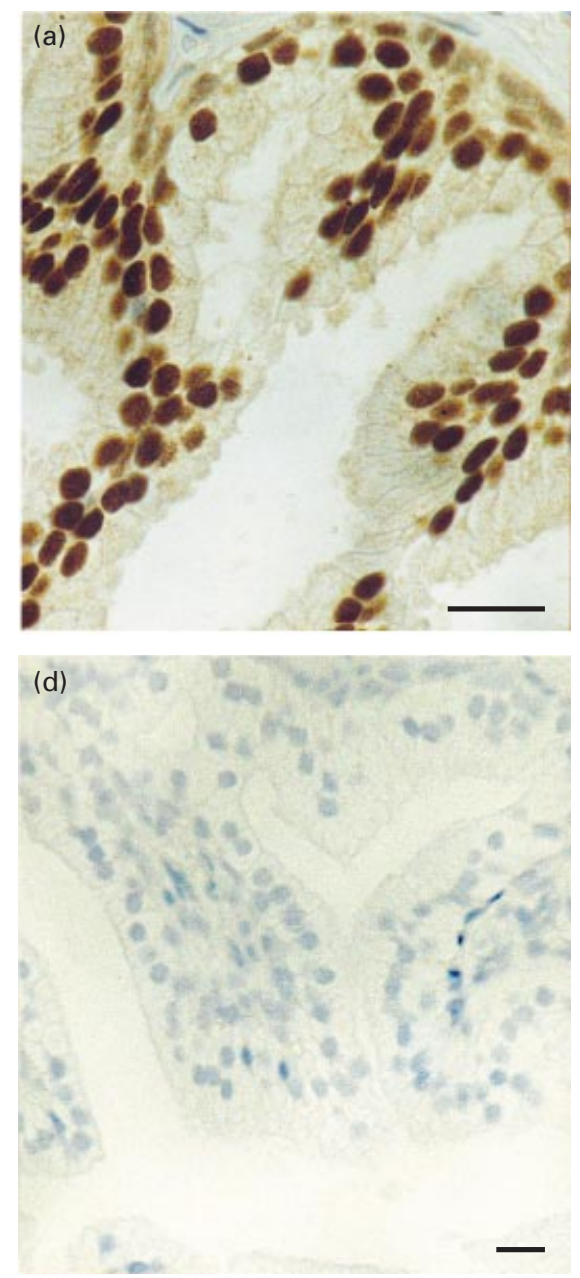
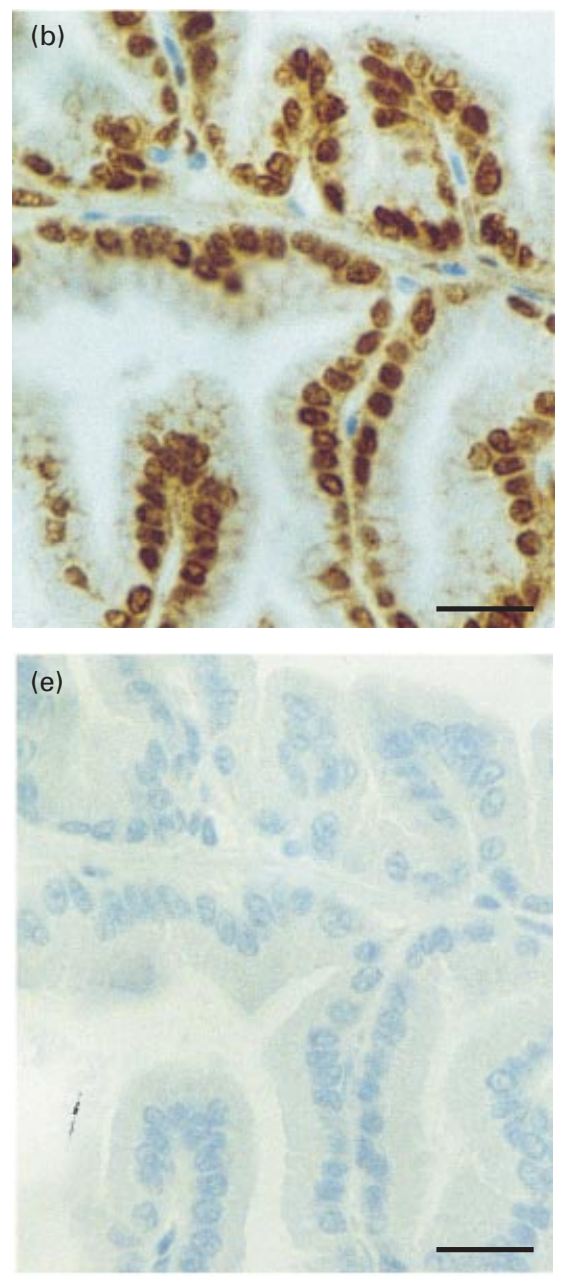
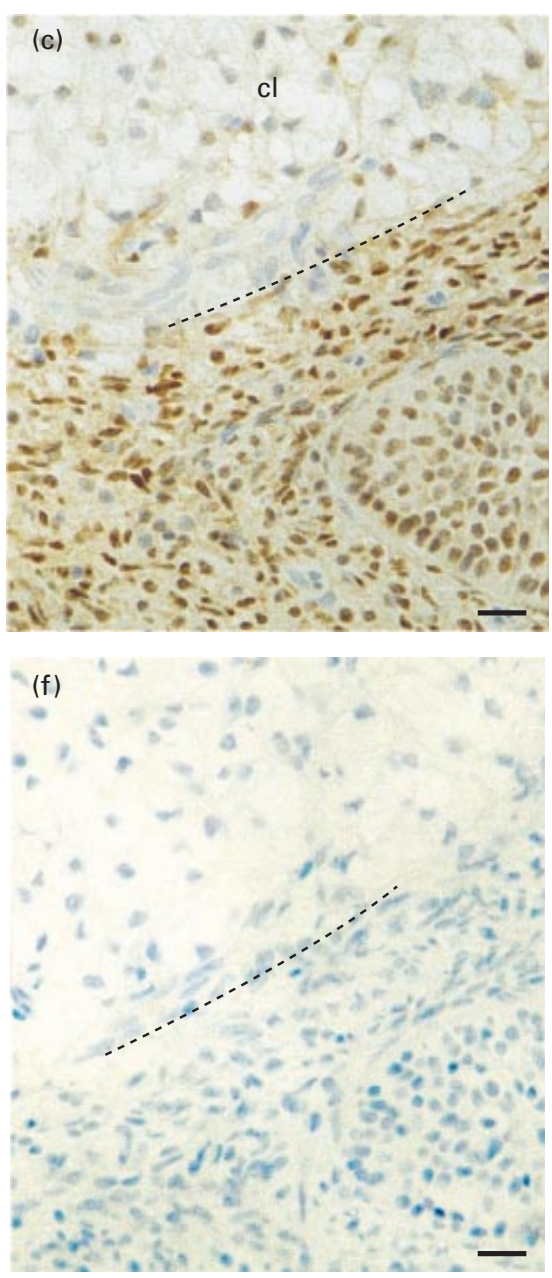

Fig. 3. Control sections for immunohistochemical staining for androgen receptors in canine ovary. (a-c) Human prostate tissue, canine prostate tissue and canine ovarian tissue, respectively, stain positive for androgen receptors. cl: corpus luteum with positive nuclear staining for androgen receptors. ( $\mathrm{d}-\mathrm{f})$ Negative controls: sections of the same human prostate tissue, canine prostate tissue and canine ovarian tissue, respectively, stain negative for androgen receptors after omission of the primary antibody. Scale bars represent $25 \mu \mathrm{m}$.

Among mesenchymal groups of cells, staining scores for androgen receptors were highest in stroma cells and lowest in theca interna cells of tertiary follicles. The intensity and total scores of the ovarian stroma were significantly higher than those of the theca interna of tertiary follicles $(P<0.01)$. Stromal cells of the tunica albuginea stained positive less frequently than the other stromal cells, but with the same intensity. Therefore, the thecal layers of tertiary follicles and the tunica albuginea appeared as regions that stained positive for androgen receptor markedly less than did the stroma of the ovarian cortex.

Cell nuclei of the corpora lutea stained with a low intensity that was intermediate between that of the primary and secondary follicles. In corpora lutea, cell nuclei stained positive less frequently than did cell nuclei in secondary and tertiary follicles $(P<0.01)$ and the total score was significantly lower than it was for tertiary follicles $(P<0.05)$. Weak cytoplasmic staining for androgen receptors was observed in luteal cells.

\section{Cyclic variations of androgen receptor expression}

Cyclic changes in staining scores for androgen receptors (Figs 5-7) were only significant for the intensity and total scores of the cortical tubules, and the proportional scores of the tertiary follicle $(P<0.05)$. In the other groups of cells, no significant changes were observed, although the lowest scores were always observed during early metoestrus, except for scores in the corpus luteum and the intensity score of the surface epithelium. In the corpus luteum, the lowest scores were observed during oestrus. Cytoplasmic staining was observed in all the corpora lutea during early metoestrus, but in the corpora lutea of only one ovary during oestrus, late metoestrus, pregnancy and the postpartum period, respectively. The stage during which the highest staining scores were observed varied among the different groups of cells. In the theca cells of secondary follicles, the highest staining scores were observed during pro-oestrus, whereas in the stromal cells and theca interna 

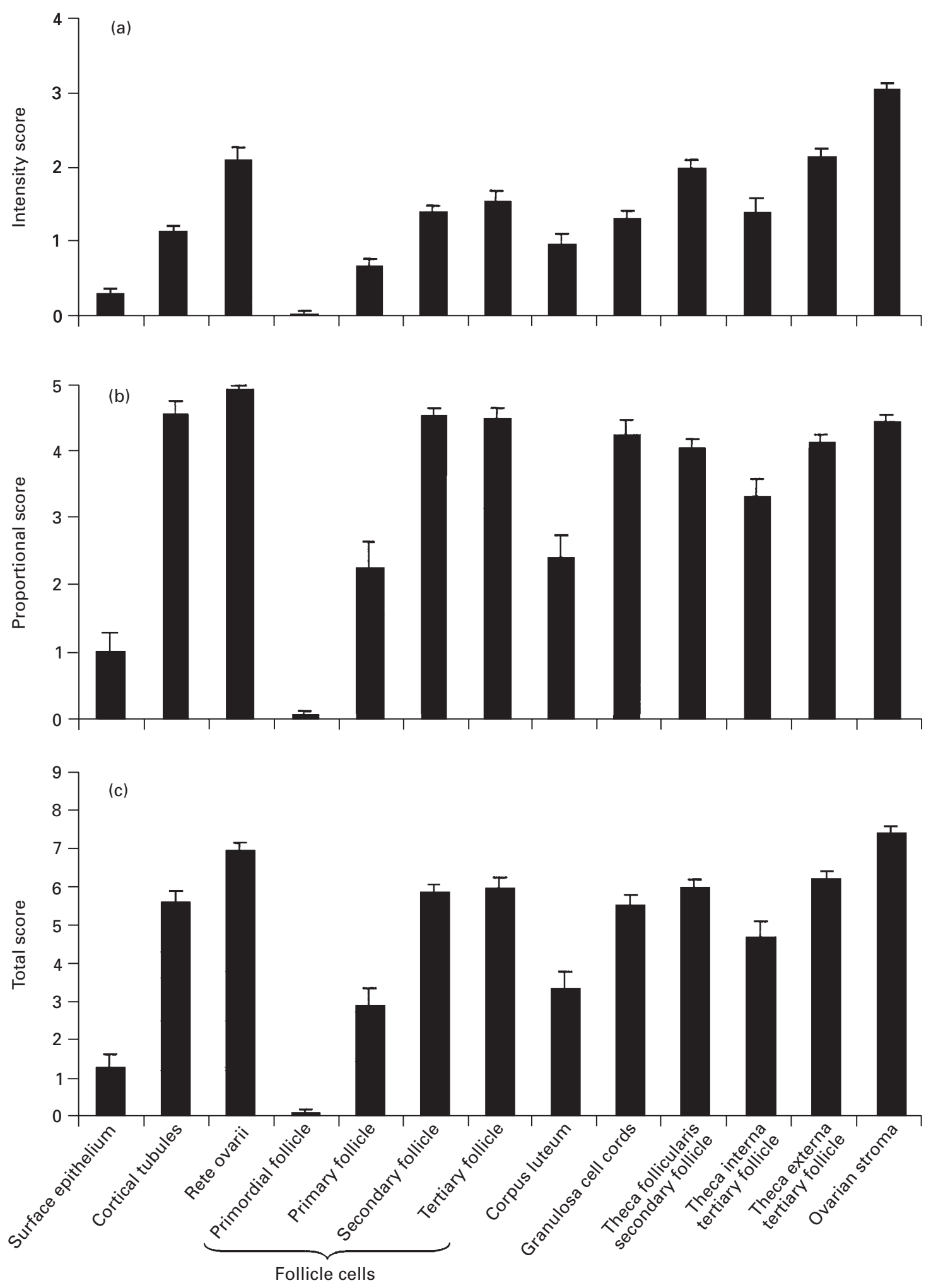

Fig. 4. Mean ( \pm SEM) (a) intensity, (b) proportional and (c) total staining scores for androgen receptors in different groups of cells in histological sections of 68 canine ovaries, irrespective of stage of the oestrous cycle. 


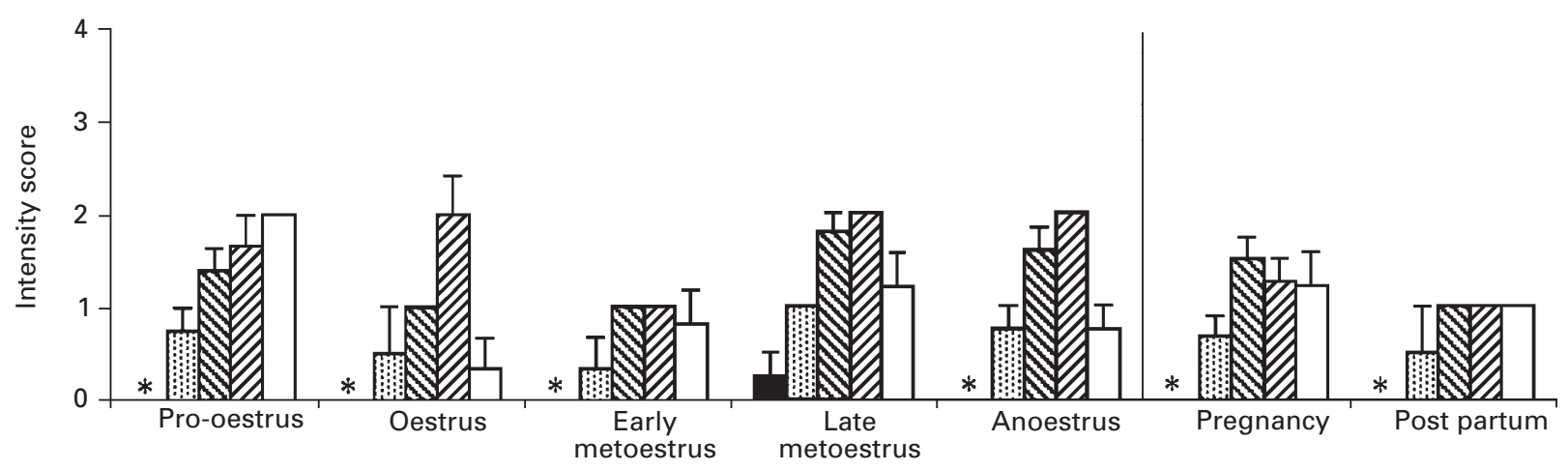

Fig. 5. Mean ( \pm SEM) staining intensity scores for androgen receptors in different stages of follicles and corpora lutea grouped by stage of the oestrous cycle in 34 bitches. $\mathbf{\square}$ : Primordial follicle; 圆: primary follicle; $\mathbb{\mathbb { N }}$ : secondary follicle; 循: tertiary follicle; $\square$ : corpus luteum. *Group of cells not found.

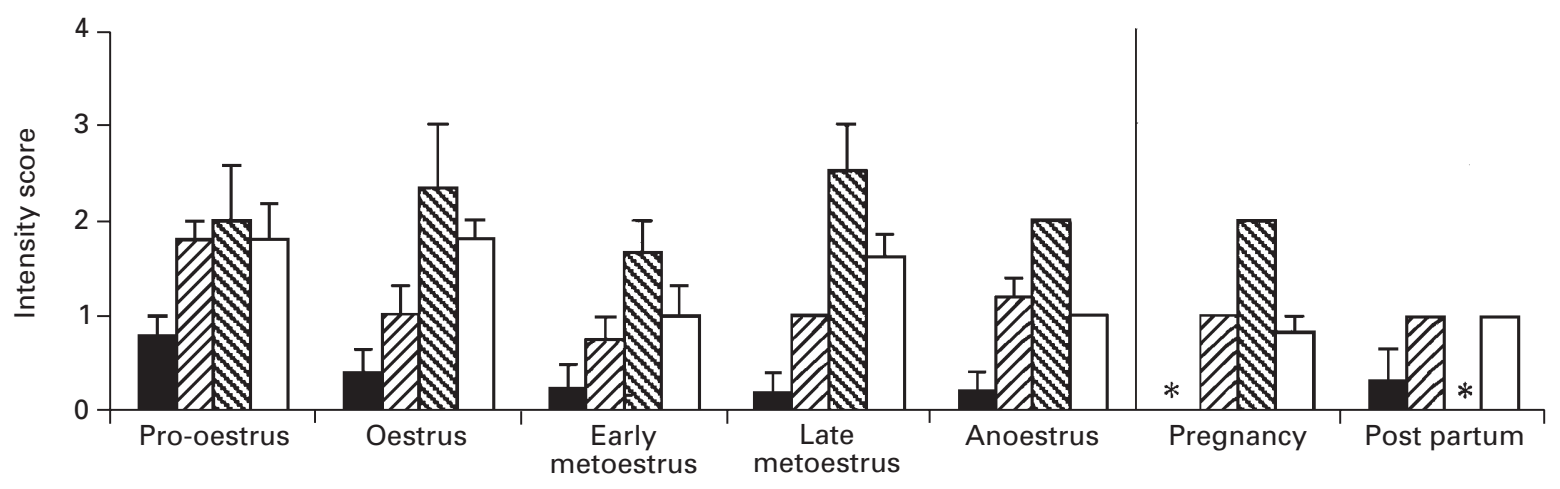

Fig. 6. Mean $( \pm$ SEM) staining intensity scores for androgen receptors in ovarian epithelia and granulosa cell cords grouped by stage of oestrous cycle in 34 bitches. $\square$ : Surface epithelium; 西: cortical tubules; $\mathbb{\mathbb { N }}$ : rete ovarii; $\square$ : granulosa cell cords. *Group of cells not found.

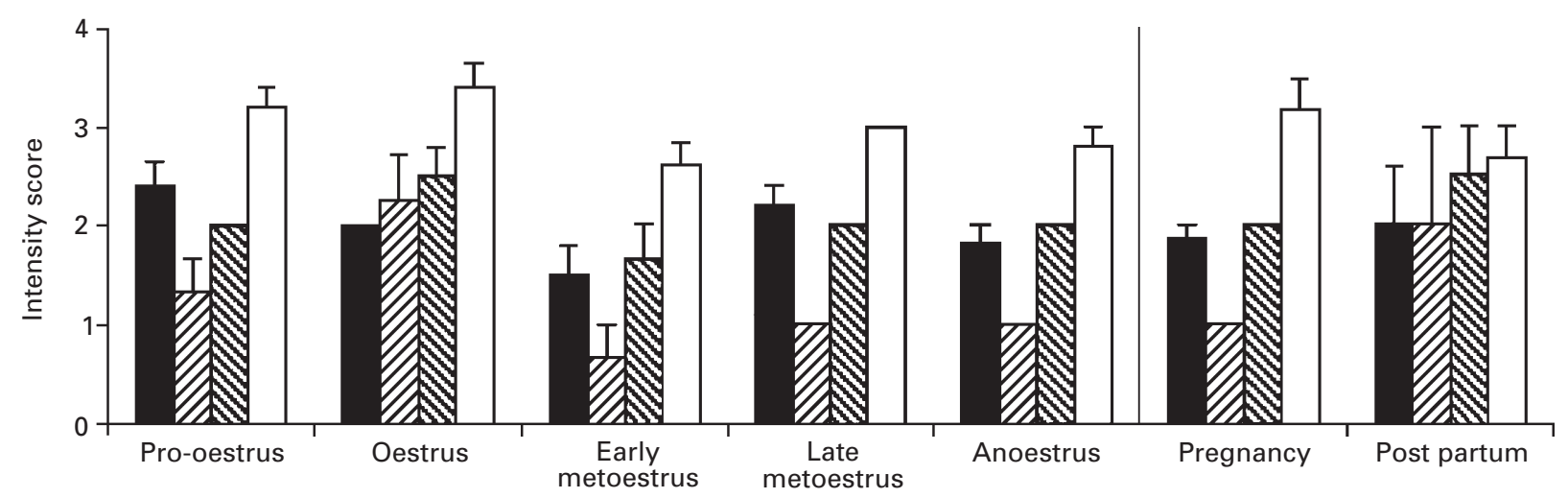

Fig. 7. Mean ( \pm SEM) staining intensity scores for androgen receptors in ovarian stromal cells grouped by stage of oestrous cycle in 34 bitches. $\mathbf{\square}$ : Theca follicularis; 侖: theca interna; $\mathbb{\mathbb { N }}$ : theca externa; $\square$ : ovarian stroma.

cells of tertiary follicles, the highest staining scores were observed during oestrus. At oestrus, staining for androgen receptors in preantral follicles was decreased, but increased in tertiary-antral follicles. In tertiary follicles, the lowest intensity staining for androgen receptors was observed during early metoestrus.
Androgen receptor expression during pregnancy and post partum

No significant differences were found in any of the groups of cells when staining scores during pregnancy or the postpartum period were compared with staining scores 
during those cycle stages when similar serum hormone concentrations are observed, that is, early metoestrus and anoestrus.

\section{Correlations between steroid hormone concentrations and androgen receptor expression}

Few correlations were found between androgen receptor expression in the different groups of ovarian cells and the serum concentrations of the sex steroid hormones.

The serum progesterone concentration was negatively correlated with the intensity and total scores in the cortical tubules $\left(r_{\mathrm{s}}=0.49\right.$ and 0.49 , respectively) and in the granulosa cells of secondary follicles $\left(r_{\mathrm{s}}=0.52\right.$ and 0.53 , respectively). A negative correlation was also found between the serum progesterone concentration and the intensity, proportional and total scores of the follicle cells of tertiary follicles $\left(r_{\mathrm{s}}=0.58,0.71\right.$ and 0.64 , respectively).

Oestradiol concentration was positively correlated with the intensity scores of the stroma $\left(r_{\mathrm{s}}=0.45\right)$ and the theca interna of tertiary follicles $\left(r_{\mathrm{s}}=0.66\right)$, with the proportional scores of the theca externa of tertiary follicles $\left(r_{\mathrm{s}}=0.60\right)$ and with the total scores of the cortical tubules $\left(r_{\mathrm{s}}=0.46\right)$ and stroma $\left(r_{\mathrm{s}}=0.45\right)$.

The testosterone concentration was positively correlated with the proportional and total scores of the stroma $\left(r_{\mathrm{s}}=0.54\right.$ and 0.51 , respectively).

\section{Discussion}

In this study, immunostaining for androgen receptors was observed in 13 different groups of cells of the canine ovary. Therefore, in dogs as in other species, androgens must have important roles in ovarian function as indicated by the widespread expression of androgen receptors in ovarian cells (Ahonen et al., 2000). Androgen receptors have been detected immunohistochemically in the ovaries of various species (Hild-Petito et al., 1991; Horie et al., 1992; Chadha et al., 1994; Suzuki et al., 1994; Tetsuka et al., 1995; Garrett and Guthrie, 1996; Hillier et al., 1997; Slomczynska and Szoltys, 1997; Tetsuka and Hillier, 1997; Vendola et al., 1998; Odore et al., 1999; Ahonen et al., 2000; Saunders et al., 2000; Szoltys and Slomczynska, 2000). Some authors state that androgen receptors are observed only in the nuclei of positive cells (Suzuki et al., 1994; Garrett and Guthrie, 1996), although rat corpora lutea express a weak, mainly cytoplasmic, staining for androgen receptors (Slomczynska and Szoltys, 1997; Szoltys and Slomczynska, 2000). In general, in the present study, nuclear staining for androgen receptors was observed in the canine ovary, although specific cytoplasmic staining was found in cells of the corpora lutea. A predominantly cytoplasmic localization of ligand-free androgen receptors has been observed in fluorescence studies of different living cell lines (Tyagi et al., 2000). After binding of androgens, androgen receptors were observed to be translocated into the cell nucleus within 20-60 min. As immunohistochemical staining methods, such as those used in the present study, visualize an epitope specific for a certain protein, positive immunostaining indicates only where certain proteins are expressed but not whether the detected protein is in an active or an inactive state. Therefore, conclusions on receptor functionality should be considered in light of these restrictions of the technique.

Nuclear staining for androgen receptors was observed in the cells of the cortical tubules of the canine ovary, which are subepithelial structures that become more prominent as the bitch advances in age (Andersen and Simpson, 1973). Cortical tubules probably result from the entrapment of ovarian surface epithelium within the stroma after ovulation to form an inclusion cyst, as in human ovaries (Resta et al., 1987), where such cysts show strong nuclear reactivity for androgen receptors (Chadha et al., 1994). The reason for this androgen receptivity of the cortical tubules and surface epithelium is not clear. The ovarian surface epithelium is one of the least understood components of the ovary and, for example, in human ovarian surface epithelium, steroid hormones had no effect on the proliferation rates of the epithelial cells in vitro (Karlan et al., 1995).

Androgen receptor gene expression has been observed in theca interna and stromal cells (Weil et al., 1998). In women, the intensity of immunostaining for androgen receptors in thecal cells was weaker than it was in follicle cells (Horie et al., 1992), whereas in pigs (Garrett and Guthrie, 1996) and rats (Tetsuka et al., 1995), the cells of the theca interna were devoid of androgen receptor immunoreactivity. Lower scores for androgen receptor immunostaining were observed in canine theca interna cells than in follicle cells and theca externa cells, except for the intensity score during pro-oestrus. This finding is in contrast with the results of progesterone receptor immunostaining in the canine ovary, where a higher staining intensity was observed in the theca interna than in follicle cells and theca externa cells (Vermeirsch et al., 2001). These high staining scores for progesterone receptors in theca interna cells indicate that progesterone action on granulosa cells is a paracrine event via theca cells. In contrast, androgens are produced by $\mathrm{LH}$-stimulated thecal cells (Tetsuka et al., 1995) and act via granulosa cell androgen receptors to modulate follicular responsiveness to gonadotrophins (Hillier et al., 1997; Ahonen et al., 2000). Therefore, in the cells of the theca interna, androgen production is probably more important than androgen receptivity.

Only a weak reaction for androgen receptors was observed in primordial and primary follicles, in accordance with findings in other species (Hild-Petito et al., 1991; Horie et al., 1992; Suzuki et al., 1994). Androgen receptor gene expression is also weak or absent in the primary follicles of primates (Weil et al., 1998). Therefore, androgens may be of minor importance in early preantral follicles. In rat ovaries, the most intense staining for androgen receptors was observed in preantral-early antral follicles (Tetsuka et al., 1995). In bitches, staining for androgen receptors increased 
from primary follicles to secondary-preantral follicles to tertiary-antral follicles. A further increase in the size of antral follicles is associated with a decrease in androgen receptor expression in rats, pigs and primates (Tetsuka et al., 1995; Garrett and Guthrie, 1996; Hillier et al., 1997) and is also associated with the decreased expression of androgen receptor mRNA in primate antral follicles (Weil et al., 1998). This decrease in androgen receptor expression in follicle cells during advanced preovulatory development is in response to stimulation by FSH (Tetsuka et al., 1995; Hillier et al., 1997). An elaborate interaction between FSH and androgens seems to regulate androgen receptor expression in follicle cells (Tetsuka and Hillier, 1997). Paracrine androgen action in granulosa cells is converted from stimulation to inhibition as follicles mature. Granulosa cells in large antral follicles are protected against this inhibition by a development-related decrease in androgen receptor expression, which promotes preovulatory follicular dominance (Hillier et al., 1997). As the decline in nuclear androgen receptor distribution in growing antral follicles in rats shows a characteristic centrifugal pattern, it has been suggested that it is correlated with the morphological differentiation of the granulosa layer (Szoltys and Slomczynska, 2000) and therefore undifferentiated granulosa cells are the main ovarian target cells for androgens (Slomczynska and Szoltys, 1997). The results of the present study do not exclude such a decrease in androgen receptor immunostaining in advanced preovulatory follicles in the canine ovary. In one oestrous ovary, a weaker staining intensity was observed in fewer cells in a luteinizing tertiary follicle than in a large antral follicle. In a different oestrous ovary, a luteinizing tertiary follicle that had just ovulated was completely devoid of staining for androgen receptors. A typical feature of bitches is that tertiary follicles luteinize just before ovulation (England, 1998) and therefore luteinizing follicles can be seen as preovulatory follicles. Some indications of a decreased androgen receptor immunostaining in these follicles were observed in the present study, although a more detailed study should be done on canine ovaries sampled during oestrus, which includes monitoring of the serum FSH concentrations, before definite conclusions can be drawn.

As in other species (Hild-Petito et al., 1991; Horie et al., 1992; Tetsuka et al., 1995; Duffy et al., 1999; Odore et al., 1999), androgen receptor immunostaining in bitches was present in the corpora lutea during the different cycle stages. This finding indicates a local androgen action within the corpus luteum during the reproductive cycle (HildPetito et al., 1991; Duffy et al., 1999). Although few studies have examined the direct effects of androgens on luteal cells, most authors suggest that luteal progesterone synthesis is inhibited by androgens (Sridaran and Gibori, 1981; Castracane et al., 1983; Polan et al., 1986). In bitches, progesterone production starts in oestrus and reaches a maximum amount during early metoestrus (Concannon, 1986b). It is possible that androgen action on corpora lutea has to be minimal during these stages, which would explain why the immunostaining for androgen receptors in canine corpora lutea is rather weak and present in fewer cells $(<10 \%)$ during oestrus and also in early metoestrus than it is during the other cycle stages (>10\%). In general, in corpora lutea, fewer cells stained positive for androgen receptors and with a lower intensity compared with the follicle cells of the larger secondary and tertiary follicles. Specific staining for androgen receptors in primates is also low in luteal cells compared with granulosa cells of the same ovaries (Hillier et al., 1997). In cows, the low staining in corpora lutea and in luteal cysts has been ascribed to the high progesterone concentrations present in luteal tissues, which induce direct downregulation of androgen receptors (Odore et al., 1999). In the present study, no correlations were found between the serum progesterone concentrations and the immunostaining for androgen receptors in corpora lutea, but it is possible that local progesterone concentrations are much higher in corpora lutea than they are in follicles and may induce downregulation of androgen receptors in the luteal cells, especially during those stages at which progesterone production is high. The scarcity of correlations between androgen receptor immunostaining and the serum concentrations of sex steroid hormones indicates that other factors regulate the presence of androgen receptors in the canine ovary.

The authors are grateful to J. De Schepper, C. De Prest, P. Herbots and P. and J. Vander Cruyssen for assistance with the sample collections. They thank L. Standaert for the immunohistochemical staining of the tissue sections.

\section{References}

Ahonen MH, Zhuang YH, Aine R, Ylikomi T and Tuohimaa P (2000) Androgen receptor and vitamin $\mathrm{D}$ receptor in human ovarian cancer: growth stimulation and inhibition by ligands International Journal of Cancer 86 40-46

Andersen AC and Simpson ME (1973) The Ovary and Reproductive Cycle of the Dog (Beagle) pp 1-282. Geron-X, Palo Alto, CA

Castracane VD, Wright E and Czar PL (1983) The effect of testosterone on human chorionic gonadotropin-stimulated ovarian steroidogenesis in vivo in the baboon Fertility and Sterility $\mathbf{4 0} 683-687$

Chadha S, Pache TD, Huikeshoven FJM, Brinkmann AO and Van der Kwast TH (1994) Androgen receptor expression in human ovarian and uterine tissue of long term androgen-treated transsexual women Human Pathology 25 1198-1204

Concannon PW (1986a) Canine pregnancy and parturition Veterinary Clinics of North America: Small Animal Practice 16 453-475

Concannon PW (1986b) Canine physiology of reproduction. In Small Animal Reproduction and Fertility. A Clinical Approach to Diagnosis and Treatment pp 23-77 Ed. TJ Burke. Lea and Febiger, Philadelphia

Concannon PW, McCann JP and Temple M (1989) Biology and endocrinology of ovulation, pregnancy and parturition in the dog Journal of Reproduction and Fertility Supplement 39 3-25

Coryn M, De Moor A, Bouters R and Vandeplassche M (1981) Clinical, morphological and endocrinological aspects of cryptorchidism in the horse Theriogenology 16 489-496

Duffy DM, Abdelgadir SE, Stott KR, Resko JA, Stouffer RL and ZelinskiWooten MB (1999) Androgen receptor mRNA expression in the Rhesus monkey ovary Endocrine 11 23-30

England GCW (1998) Allen's Fertility and Obstetrics in the Dog pp 1-8 Eds JB Sutton and DT Swift. Blackwell Science Ltd, Oxford 
Evans HE (1993) Prenatal development. In Miller's Anatomy of the Dog pp 44-48 Ed. HE Evans. WB Saunders Company, Philadelphia.

Garrett WM and Guthrie HD (1996) Expression of androgen receptors and steroidogenic enzymes in relation to follicular growth and atresia following ovulation in pigs Biology of Reproduction 55 949-955

Harlow CR, Hillier SG and Hodges JK (1986) Androgen modulation of follicle-stimulating hormone-induced granulosa cell steroidogenesis in the primate ovary Endocrinology 119 1403-1405

Harlow CR, Shaw HJ, Hillier SG and Hodges JK (1988) Factors influencing follicle-stimulating hormone-responsive steroidogenesis in marmoset granulosa cells: effects of androgens and the stage of follicular maturity Endocrinology 122 2780-2787

Henry M, Figueiredo AEF, Palhares MS and Coryn M (1987) Clinical and endocrine aspects of the oestrous cycle in donkeys (Equus asinus). Journal of Reproduction and Fertility Supplement 35 297-303

Hild-Petito S, West NB, Brenner RM and Stouffer R (1991) Localization of androgen receptor in the follicle and corpus luteum of the primate ovary during the menstrual cycle Biology of Reproduction 44 561-568

Hillier SG and Tetsuka M (1997) Role of androgens in follicle maturation and atresia Baillière's Clinical Obstetrics and Gynaecology 11 249-260

Hillier SG, Tetsuka M and Fraser HM (1997) Location and developmental regulation of androgen receptor in primate ovary Human Reproduction 12 107-111

Horie K, Takakura K, Fujiwara H, Suginami H, Liao S and Mori T (1992) Immunohistochemical localization of androgen receptor in the human ovary throughout the menstrual cycle in relation to oestrogen and progesterone receptor expression Human Reproduction 7 184-190

Karlan BY, Jones J, Greenwald M and Lagasse LD (1995) Steroid hormone effects on the proliferation of human ovarian surface epithelium in vitro. American Journal of Obstetrics and Gynecology 173 97-104

International Committee on Veterinary Histological Nomenclature (1994) Nomina Histologica 2nd Edn p. 38. Cornell, New York

Odore R, Re G, Badino P, Donn A, Vigo D, Biolatti B and Girardi C (1999) Modifications of receptor concentrations for adrenaline, steroid hormones, prostaglandin $\mathrm{F}_{2 \alpha}$ and gonadotropins in hypophysis and ovary of dairy cows with ovarian cysts Pharmacological Research 39 297-304

Polan ML, Seu D and Tarlatzis B (1986) Human chorionic gonadotropin stimulation of estradiol production and androgen antagonism of gonadotropin-stimulated responses in cultured human granulosa-luteal cells Journal of Clinical Endocrinology and Metabolism 62 628-633

Resta L, De Benedictic G, Scordari MD, Orlando E, Borraccino V and Milillo F (1987) Hyperplasia and metaplasia of ovarian surface epithelium in women with endometrial carcinoma: suggestion for a hormonal influence in ovarian carcinogenesis Tumori 73 249-256

Saunders PTK, Millar MR, Williams K et al. (2000) Differential expression of estrogen receptor $\alpha$ and $\beta$ and androgen receptor in the ovaries of marmosets and humans Biology of Reproduction 63 1098-1105

Slomczynska M and Szoltys M (1997) Immunohistochemical localization of androgen receptor (AR) in rat ovary Folia Histochemica et Cytobiologica 35 101-102

Sridaran R and Gibori G (1981) Induction of luteolysis by dihydro- testosterone in the pregnant rat American Journal of Physiology 241 E444-A448

Suzuki T, Sasano H, Kimura N, Tamura M, Fukaya T, Yajima A and Nagura H (1994) Immunohistochemical distribution of progesterone, androgen and oestrogen receptors in the human ovary during the menstrual cycle: relationship to expression of steroidogenic enzymes Human Reproduction 9 1589-1595

Szoltys M and Slomczynska M (2000) Changes in distribution of androgen receptor during maturation of rat ovarian follicles Experimental and Clinical Endocrinology and Diabetes 108 228-234

Tetsuka M and Hillier SG (1997) Differential regulation of aromatase and androgen receptor in granulosa cells Journal of Steroid Biochemistry and Molecular Biology 61 233-239

Tetsuka M, Whitelaw PF, Bremner WJ, Millar MR, Smyth CD and Hillier SG (1995) Developmental regulation of androgen receptor in rat ovary Journal of Endocrinology 145 535-543

Tyagi R, Lavrovsky Y, Ahn SC, Song CS, Chatterjee B and Roy AK (2000) Dynamics of intracellular movement and nucleocytoplasmic recycling of the ligand-activated androgen receptor in living cells Molecular Endocrinology 14 1162-1174

Vendola KA, Zhou J, Adesanya OO, Weil SJ and Bondy CA (1998) Androgens stimulate early stages of follicular growth in the primate ovary Journal of Clinical Investigation $1012622-2629$

Vermeirsch H, Simoens P, Lauwers H and Coryn M (1999) Immunohistochemical detection of estrogen receptors in the canine uterus and their relation to sex steroid hormone levels Theriogenology 51 729-743

Vermeirsch H, Simoens P, Hellemans A, Coryn M and Lauwers H (2000a) Immunohistochemical detection of progesterone receptors in the canine uterus and their relation to sex steroid hormone levels Theriogenology $53773-788$

Vermeirsch H, Simoens P and Lauwers H (2000b) Immunohistochemical detection of estrogen and progesterone receptors in the canine pregnant uterus and placental labyrinth Anatomical Record 260 42-50

Vermeirsch H, Simoens P, Coryn M and Van den Broeck W (2001) Immunolocalization of progesterone receptors in the canine ovary and their relation to sex steroid hormone concentrations Reproduction 122 73-83

Weil SJ, Vendola K, Zhou J, Adesanya OO, Wang J, Okafor J and Bondy CA (1998) Androgen receptor gene expression in the primate ovary: cellular localization, regulation, and functional correlations Journal of Clinical Endocrinology and Metabolism 83 2479-2485

Weil SJ, Vendola K, Zhou J and Bondy CA (1999) Androgen and folliclestimulating hormone interactions in primate ovarian follicle development Journal of Clinical Endocrinology and Metabolism 84 2951-2956

Received 21 March 2001.

First decision 4 June 2001.

Accepted 5 July 2001. 